Jpn. J. Phys. Fitness Sports Med. 1996, $45: 419 \sim 428$

\title{
PREVALENCE OF DISORDERED EATING PATTERNS AND MENSTRUAL STATUS IN JAPANESE FEMALE ATHLETES
}

\author{
Goroh OKano ${ }^{1)}$, Yuji Sato ${ }^{2)}$, Howard TarnofF ${ }^{3)}$, Isamu Nemoto ${ }^{4)}$, \\ Akira NaKamoto ${ }^{5)}$, Kunpei TOKUyama ${ }^{6)}$, Masashige Suzuki ${ }^{6)}$ \\ and YOSHIKATSU NAKAI ${ }^{7)}$
}

\begin{abstract}
This study investigated the desire and its reasons for weight loss, the prevalence of disordered eating patterns and menstrual status, by using written questionnaires and Eating Attitude Test-26 $($ EAT-26), in Japanese female athletes $(n=1000)$ and nonathletic controls $(n=593)$. Athletes were divided into the following 6 categories: technical $(n=84)$, endurance I $(n=84)$ and II $(n=76)$, aesthetic $(n=120)$, ball-game $(n=447)$, and power sports $(n=189)$. Endurance I consisted of athletes competing in sports where leanness were considered important, while endurance II consisted of athletes competing in sports where leanness is less important. In each category, about four fifths of the athletes wanted to reduce their present weight. As to the reasons for weight loss, the athletes, especially those in the categories of endurance I (79\%), power (52\%) and aesthetic (34\%) sports, reported that they prefer to be thin for improving their athletic performance. The prevalence of disordered eating patterns estimated by EAT-26 was significantly higher $(\mathrm{P}<0.05)$ in the athletes of endurance I (20\%) and aesthetic (12\%) groups than in the nonathletic controls $(3 \%)$. In the athletes of these two sporting event categories, higher rates of amenorrhea (endurance I $20 \%$ and aesthetic $7 \%$ vs. nonathlets $1 \%$ ) were found to be accompanied by lower values of obesity index and BMI. These data indicate a significantly higher prevalence of disordered eating patterns and menstrual dysfunction in the athletes involved in sports where leanness is emphasized, and a close relationship among undernutrition, low body weight and menstrual dysfunction.
\end{abstract}

(Jpn. J. Phys. Fitness Sports Med. 1996, $45: 419 \sim 428$ )

key words : Japanese female athletes, weight concern, EAT-26, disordered eating patterns, menstrual dysfunction

\section{Introduction}

Nutritional problems are no doubt harmful to health and athletic performance. However, several studies have shown that nutritional intake in Japanese athletes is insufficient for their nutritional needs ${ }^{16,18.23)}$. The Japanese Olympic Com- mittee and Japan Amateur Sports Association conducted a survey and concluded that the nutritional status of Japanese candidates for the Olympic Games could be described as satisfactory in only nine percent of the athletes ${ }^{18)}$. In addition, energy and nutrient intake of adolescent Japanese athletes who belonged to a top-ranking high school track
${ }^{1)}$ 札幌医科大学医学部運動科学教室 T060 札幌市中央区南 1 条西17丁目

2) 埼玉県立衛生短期大学一般教育 厂338 浦和市上大久保519番地

${ }^{3)}$ 北海道医療大学基礎教育部 T061-02 石狩郡当別町金沢1757番地

${ }^{4)}$ 日本女子体育大学運動生理学研究室 テ157 東京都世田谷区北烏山8-19-1

5) 東京女子体育大学運動生理学研究室 テ186 東京都国立市富士見台4-30-1

6) 筑波大学体育科学系運動 - 栄養生化学研究室 テ305つくば市天王台1-1-1

7) 京都大学医療技術短期大学部 看護学科 于606 京都市左京区聖護院川原町53
Laboratory of Physiology in Exercise and Nutrition, School of Medicine, Sapporo Medical University, Chuo-ku, Sapporo 060 Department of General Education, Saitama College of Health, Kamiohkubo, Urawa 338

Department of Basic Education, Health Sciences University of Hokkaido, Tobetsu, Ishikari-gun 061-02

Department of Applied Physiology, Japan Women's College of Physical Education, Setagaya-ku, Tokyo 157

Department of Exercise Physiology, Tokyo Women's College of Physical Education, Kunitachi, Tokyo 186

Institute of Health and Sports Sciences, The University of Tsukuba, Niihari-gun, Ibaragi 305

College of Medical Technology, Kyoto University, Sakyo-ku, Kyoto 606 
and field or basketball team were reported to be inadequate in meeting their daily needs and significantly less than their Chinese counterparts ${ }^{16)}$.

Recent studies published in industrially advanced western countries have indicated that athletes, especially female athletes, have a strong desire to be thin and practice weight control methods similar to those in individuals with eating disorders $(E D)^{2,20,22)}$. Using a large population of elite female athletes and a strict DSM- III-R criteria $^{1)}$, Sundgot-Borgen ${ }^{20)}$ recently confirmed that a significantly higher number of athletes than nonathletic controls were found to actually suffer from ED, particularly athletes competing in sports in which leanness or a specific weight limits were considered important. As a consequence of extreme dietary restriction, a number of female athletes have been reported to experience health problems, such as amenorrhea $^{3,12,13,14)}$ and consequent loss of bone mass ${ }^{12.14)}$. These eating problems in female athletes are thought to come from the demand to be thin for optimizing performance, in addition to a pervasive sociocultural-driven desire to be thin $^{22)}$.

At present, the sociocultural aspects of Japan do not differ greatly from those of other industrially advanced western countries. In addition, many studies have revealed that Japanese female athletes had lower energy and nutrient intake than their estimated daily needs ${ }^{16,18,23)}$. This suggests that a number of Japanese female athletes suffer from disordered eating patterns and resultant health problems. However, information on this area is still very limited. The aims of this study are to provide descriptive information concerning the drive for thinness, the prevalence of disordered eating patterns and menstrual status in female Japanese athletes.

\section{Materials and Methods}

\section{A. Subjects}

One thousand female athletes $(19.3 \pm 1.1 \mathrm{yr})$ and 593 nonathletes $(18.9 \pm 0.8 \mathrm{yr})$ participated in this survey. The athletes were recruited from various Japanese colleges where they majored in physical education and from sporting teams that are company owned. Nonathletic controls were obtained from age-matched college students. The athletes represented 39 sporting events. For the purpose of the analyses, these 39 sporting events were divided into the following 6 sport categories: technical $(n=84)$, endurance I $(n=84)$, endurance II $(n=76), \quad$ aesthetic $(n=120), \quad$ ball-game $(n=$ $447)$, and power sports $(n=189)$. Endurance group was divided into two groups. Endurance I represents sports where leanness is considered important (e. g., middle/long distance run, orienteering, etc.), while endurance II represents sports where leanness is less important (e. g., swimming, rowing, etc.).

\section{B. Questionnaire survey}

The method of this study and criteria for participation were explained to subjects by way of written instructions. A written questionnaire asked subjects as to their physical characteristics, their desire to be thin and its reason, and menstrual history. A short version of Eating Attitude Test $(\mathrm{EAT}-26)^{8)}$ translated into Japanese was also used to obtain information about the prevalence of disordered eating patterns.

1) Anthropometric measurements

The age, height, weight (WT) and ideal weight of the subjects were asked in the questionnaire. The obesity index was estimated by the following formula : [(present WT/standard WT) -1] $\times 100$. The standard body weight was calculated by Hirata's method ${ }^{15)}$.

2) Drive for thinness

Questionnaires asked how the subjects want to 
change their weight, and, if they want to reduce their weight, why.

3) Prevalence of disordered eating patterns

EAT $-26^{8)}$ contains 26 items which were rated on a 6-point scale with descriptors ranging from "always" to "never". The scoring in EAT-26 is as follows: 3 points for "always", 2 points for "usually", 1 point for "often", and 0 points for "sometimes", "rarely" and "never". Subjects whose total score in EAT-26 was 20 or above were judged to be individuals with disordered eating patterns, based on the recommendation of Garner $^{8)}$.

5) Menstrual status

The information on the current menstrual status was obtained through the written questionnaire. Subjects reporting menstrual cyclic lengths of 25 $\sim 38$ days were classified as eumenorrheic. Amenorrheic subjects were those reporting cessation of menstruation for the previous 3 months or more (excluding pregnancy). Subjects who did not fit into the above two categories were then classified as a combined group of oligomenorrhea and hypermenorrhea.

6) Statistical analysis

Kruskal-Wallis test with Dunn's post-hoc analyses or chi-square tests were used to examine differences among the various groups studied. All statistical analyses were computed using STAT FLEX (JIP Inc., Tokyo). Statistical significance for all analyses was set at the 0.05 level.

\section{Results}

Table 1 shows the anthropometric data of subjects. The athletes of power sports were the tallest, and those of ball games were the heaviest. The mean obesity index was negative in all sports categories except ball games. Athletes who belonged to endurance I $(-10.0 \%)$ and aesthetic sport $(-5.4 \%)$ had lower obesity index values than those of other groups.

Data on the desire for weight loss and its reasons are summarized in Table 2. There was no significant difference in the desire for weight loss among the groups studied. Seventy-seven to $88 \%$ of the subjects wanted to reduce their present weight. The degree of the desired weight loss the subjects hoped for was between $3.4 \sim 4.8 \mathrm{~kg}$ in absolute values and $6.5 \sim 8.7 \%$ in relative values of their present weight. A significant difference $(\mathrm{P}<0.01)$ was observed in the reason for weight loss between the nonathletic controls and the athletic groups. In the nonathletes, predominant reasons for weight loss were that they felt fat and that they preferred to slim down certain parts of their body. In contrast, $27 \sim 79 \%$ of athletes reported that they wanted to be thin in order to obtain a higher athletic performance. Athletes in endurance $\mathrm{I}(79 \%)$, power $(52 \%)$ and aesthetic (34\%) sports groups had a stronger desire to

Table 1. Physical characteristics of female athletes.

\begin{tabular}{lccccccc}
\hline & $\begin{array}{l}\text { Nonathletic } \\
\text { controls }\end{array}$ & Technical & Endurance I & Endurance II & Aesthetic & Ball-game & Power \\
\hline Height $(\mathrm{cm})$ & $158.8 \pm 5.3$ & $160.5 \pm 5.2$ & $160.0 \pm 4.8$ & $161.8 \pm 4.4^{* *}$ & $160.3 \pm 4.8^{*}$ & $162.6 \pm 5.8^{* *} 163.3 \pm 5.2^{* *}$ \\
Weight $(\mathrm{kg})$ & $52.6 \pm 6.2$ & $54.8 \pm 5.9^{*}$ & $49.4 \pm 4.8^{* *}$ & $55.5 \pm 5.0^{* *}$ & $52.0 \pm 4.7$ & $57.3 \pm 6.2^{* *} 57.2 \pm 8.6^{* *}$ \\
BMI $\left(\mathrm{kg} / \mathrm{m}^{2}\right)$ & $20.9 \pm 2.1$ & $21.2 \pm 1.6$ & $19.3 \pm 1.7^{* *}$ & $21.2 \pm 1.7$ & $20.2 \pm 1.5^{* *}$ & $21.6 \pm 1.6^{* *}$ & $21.3 \pm 3.1$ \\
Obesity index $(\%)$ & $-2.6 \pm 10.5$ & $-1.2 \pm 7.6$ & $-10.0 \pm 7.6^{* *}$ & $-0.2 \pm 9.6$ & $-5.4 \pm 7.3^{*}$ & $0.6 \pm 7.5^{* *}$ & $-0.3 \pm 12.3$ \\
\hline
\end{tabular}

Values are means $\pm \mathrm{SD}$. Significant difference between nonathletic and each athletic group, ${ }^{*} \mathrm{P}<0.05$ and ${ }^{* *} \mathrm{P}<0.01$ (Kruskal-Wallis test with Dunn's post hoc analyses). 
Table 2. Weight ideation and reduction in female athletes.

\begin{tabular}{|c|c|c|c|c|c|c|c|}
\hline & $\begin{array}{l}\text { Nonathletic } \\
\text { controls }\end{array}$ & Technical & Endurance I & Endurance II & Aesthetic & Ball-game & Power \\
\hline \multicolumn{8}{|l|}{ Weight ideation $(\%)$} \\
\hline lose & 82.0 & 82.1 & 79.8 & 84.2 & 88.3 & 81.4 & 77.2 \\
\hline maintain & 15.8 & 16.7 & 17.9 & 13.2 & 10.9 & 17.3 & 19.6 \\
\hline gain & 2.2 & 1.2 & 2.4 & 2.6 & 0.8 & 1.3 & 3.2 \\
\hline \multicolumn{8}{|l|}{ Desired weight reduction ${ }^{a}$} \\
\hline $\begin{array}{l}(\mathbf{k g}) \\
(\% \text { of present Weight })\end{array}$ & $\begin{array}{l}4.8 \pm 3.8 \\
8.7 \pm 6.3\end{array}$ & $\begin{array}{l}4.3 \pm 2.9 \\
7.6 \pm 4.6\end{array}$ & $\begin{array}{l}3.4 \pm 2.8^{* *} \\
6.5 \pm 5.3^{* *}\end{array}$ & $\begin{array}{l}4.1 \pm 3.4 \\
7.0 \pm 5.6^{*}\end{array}$ & $\begin{array}{l}4.4 \pm 2.7 \\
8.0 \pm 4.6\end{array}$ & $\begin{array}{l}4.3 \pm 3.1 \\
7.8 \pm 8.2^{* *}\end{array}$ & $\begin{array}{l}3.9 \pm 3.3 \\
6.5 \pm 4.9^{* *}\end{array}$ \\
\hline \multicolumn{8}{|l|}{ Reason for weight reduction (\%) } \\
\hline $\begin{array}{l}\text { Others making remarks about } \\
\text { them being overweight }\end{array}$ & 5.2 & 3.0 & - & 6.3 & 2.9 & 2.3 & 2.1 \\
\hline Feel fat & 51.1 & 47.0 & 10.6 & 43.8 & 45.2 & 43.2 & 24.8 \\
\hline Slimming down certain parts & & & & & & & \\
\hline $\begin{array}{l}\text { of body } \\
\text { Improvement of performance }\end{array}$ & $\begin{array}{r}36.7 \\
0.2\end{array}$ & $\begin{array}{l}21.2 \\
27.2 \ddagger\end{array}$ & $\begin{array}{c}9.1 \\
78.7 \ddagger\end{array}$ & $\begin{array}{l}15.6 \\
28.1 \ddagger\end{array}$ & $\begin{array}{l}17.3 \\
33.7 \ddagger\end{array}$ & $\begin{array}{l}23.3 \\
27.9 \ddagger\end{array}$ & $\begin{array}{l}17.9 \\
51.7 \ddagger\end{array}$ \\
\hline Model like figure & 3.9 & - & - & 3.1 & $1.0^{\top}$ & 1.1 & 0.7 \\
\hline Others & 2.9 & 1.5 & 1.5 & 3.1 & - & 2.3 & 2.8 \\
\hline
\end{tabular}

a) Values are means $\pm \mathrm{SD}$. Significantly different from nonathletic controls, ${ }^{*} \mathrm{P}<0.05$ and ${ }^{*} \mathrm{P}<0.01$ (Kruskal-Wallis test with Dunn's post hoc analyses). Significantly different from nonathletic controls, $\ddagger P<0.01$ (chi-square test).

reduce weight for improving their performance, compared with those of other sport groups.

The prevalence of disordered eating patterns, estimatedby EAT-26 (score $\geqq 20$ ), is indicated in Table 3 and 4. Total scores of EAT- 26 were significantly higher $(P<0.05$ or $P<0.01)$ in technical, endurance I, aesthetic and ball game sports groups than in the nonathletic control group. The percentage of subjects whose total score of EAT-26 was 20 or above was significantly higher $(\mathrm{P}<0.05$ or $\mathrm{P}<0.01)$ in endurance $\mathrm{I}(20.3 \%)$, aesthetic (11.6\%) and technical (8.4\%) groups than in the nonathletic control group (3.2\%) (Table 3). In these sports category groups, no significant difference in the prevalence of disordered eating patterns was observed between elite and non-elite athletes (international level 15\%, national level $17 \%$, regional level 12\%). Among the different sporting categories (Table 4), the prevalence of disordered eating patterns was significantly higher $(\mathrm{P}<0.05$ or $\mathrm{P}<0.01)$ in middle/long-distance running $(20.7 \%)$, rhythmic gymnastics (16.7\%), cheerleading (11.5\%), handball (9.9\%) and sprints $(8.7 \%)$, as compared with the nonathletic control group (3.2\%).

Table 3 also represents the current menstrual

Table 3. Eating attitudes test (EAT-26) and menstrual status.

\begin{tabular}{|c|c|c|c|c|c|c|c|}
\hline & $\begin{array}{l}\text { Nonathletic } \\
\text { controls }\end{array}$ & Technical & Endurance I & Endurance II & Aesthetic & Ball-game & Power \\
\hline \multicolumn{8}{|l|}{ EAT-26 } \\
\hline total scores ${ }^{\mathrm{a})}$ & $5.9 \pm 6.2$ & $8.6 \pm 10.3^{*}$ & $11.7 \pm 10.1^{* *}$ & $7.8 \pm 9.1$ & $9.7 \pm 8.1^{* *}$ & $7.0 \pm 6.2^{* *}$ & $7.4 \pm 7.3$ \\
\hline$\geqq 20(\%)$ & 3.2 & $8.4 \dagger$ & $20.3 \ddagger$ & 3.0 & $11.6 \ddagger$ & 5.1 & 5.3 \\
\hline \multicolumn{8}{|l|}{ Menstrual status $(\%)$} \\
\hline Eumenorrhea & 77.0 & 69.1 & 53.6 & 84.2 & 66.7 & 72.9 & 70.9 \\
\hline \multicolumn{8}{|l|}{ Oligomenorrhea and } \\
\hline Hypermenorrhea & 21.7 & 27.4 & 26.2 & 15.8 & 26.7 & 24.8 & 26.5 \\
\hline Amenorrhea & 1.4 & 3.6 & $20.2 \ddagger$ & - & $6.7 \ddagger$ & 2.2 & 2.6 \\
\hline
\end{tabular}

a) Values are means $\pm \mathrm{SD}$. Significantly different from nonathletic controls, ${ }^{*} \mathrm{P}<0.05$ and ${ }^{* *} \mathrm{P}<0.01$ (Kruskal-Wallis test with Dunn's post hoc analyses). Significantly different from nonathletic controls, $\dagger P<0.05$ and $\ddagger P<0.01$ (chi-square test). 
Table 4. Prevalence of disordered eating patterns in the athletes.

\begin{tabular}{lc}
\hline \multicolumn{1}{c}{ Sport event } & Prevalence $(\%)$ \\
\hline Nonathletes $(n=593)$ & 3.2 \\
Softball $(n=28)$ & 3.6 \\
Basketball $(n=121)$ & 5.0 \\
Soft tennis $(n=31)$ & 6.5 \\
Volleyball $(n=45)$ & 6.7 \\
Dance $(n=50)$ & 8.0 \\
High \& broad jump $(n=36)$ & 8.3 \\
Sprint $(n=79)$ & $8.7 \dagger$ \\
Gymnastic $(n=22)$ & 9.1 \\
Handball $(n=81)$ & $9.9 \ddagger$ \\
Cheerleading $(n=26)$ & $11.5 \dagger$ \\
Rhythmic gymnastic $(n=42)$ & $16.7 \ddagger$ \\
Middle \& long distance run $(n=82)$ & $20.7 \ddagger$ \\
\hline
\end{tabular}

Values are percentages of subjects whose total score in EAT-26 is at or above 20 . Significantly different from nonathletic controls, $\uparrow \mathrm{P}<0.05$ and $\ddagger \mathrm{P}<0.01$ (chi-square test).

status in the subjects. Menstrual status was varied within the different groups. The percentages of athletes who reported to have been amenorrheic for a period of 3 months or longer was significantly higher $(\mathrm{P}<0.01)$ in endurance I (20.2\%) and aesthetic (6.7\%) groups than in the nonathletic control group (1.4\%).

The relationship between menstrual status and disordered eating pattern, or menstrual status and body size is shown Table 5 . Amenorrheic athletes
(26\%) had significantly $(\mathrm{p}<0.01)$ higher prevalence of disordered eating patterns than their eumenorrheic $(6 \%)$ or oligomenorrheic plus hypermenorrheic ( $8 \%$ ) counterparts. Also, the obesity index and BMI were significantly lower $(p<0.01)$ in amenorrheic $(-9.4 \%$ and 19.6$)$ compared to eumenorrheic $(-0.6 \%$ and 21.3$)$ or oligomenorrheic plus hypermenorrheic $(-2.5 \%$ and 21.0$)$ athletes.

\section{Discussion}

Our study is the first to document that Japanese female athletes had a strong desire to be thin for the improvement of their athletic performance, and a higher number of athletes vs. non-athletes had eating attitudes and behaviors consistent with those exhibited by individuals with ED. In addition, this ED-like eating pattern was significantly more prevalent in sports where leanness is emphasized (endurance I and aesthetic group), as compared with those sporting categories without such emphasis. So far several studies have shown that the nutritional intake in Japanese female athletes is insufficient for their daily nutritional needs ${ }^{16,18,23)}$. Our present findings may partly explain why Japanese female athletes have not been able to meet their dietary needs.

Many studies ${ }^{2,20,22)}$ in advanced western coun-

Table 5. Relationship between menstrual status and disordered eating patterns, or menstrual status and body size in the athletes.

\begin{tabular}{lccc}
\hline & $\begin{array}{c}\text { Eumenorrhea } \\
(\mathrm{n}=711)\end{array}$ & $\begin{array}{c}\text { Oligomenorrhea and } \\
\text { Hypermenorrhea } \\
(\mathrm{n}=246)\end{array}$ & $\begin{array}{c}\text { Amenorrhea } \\
(\mathrm{n}=43)\end{array}$ \\
\hline $\operatorname{EAT}-26(\geqq 20)(\%)$ & $6.1 \ddagger$ & $8.3 \ddagger$ & 25.6 \\
$\operatorname{BMI}\left(\mathrm{kg} / \mathrm{m}^{2}\right)^{\text {a) }}$ & $21.3 \pm 2.0^{* *}$ & $21.0 \pm 1.7^{* *}$ & $19.6 \pm 2.2$ \\
Obesity index $(\%)^{\text {a) }}$ & $-0.6 \pm 8.7^{* *}$ & $-2.5 \pm 8.2^{* *}$ & $-9.4 \pm 9.7$ \\
\hline
\end{tabular}

a) Values are means $\pm S D$. Significantly different from amenorrheic athletes,

** $\mathrm{P}<0.01$ (Kruskal-Wallis test with Dunn's post hoc analyses) and $\ddagger \mathrm{P}<0.01$ (chi-square test) 
tries have estimated the prevalence of disordered eating patterns in athletes by using some inventories, such as $\mathrm{EAT}^{7)}$, EAT-26 $6^{8)}$ and Eating Disorder Inventory $(\mathrm{EDI})^{9)}$. As a result, the prevalence of disordered eating patterns has been reported to be significantly higher in female athletes, particularly those competing in sports in which leanness or maintenance of a specific weight is considered important, as compared with nonathletes (for example, 19\% in college female athletes, $48 \%$ in figure skaters, $30 \sim 34 \%$ in ballet dancers and $14 \%$ in runners vs. less than a few percent in nonathletes) ${ }^{22)}$. Present results that disordered eating patterns were significantly more prevalent in athletes engaged in sports, especially those in which leanness is emphasized are largely consistent with those of previous papers published in advanced western countries ${ }^{2,20.22)}$.

Sundgot-Borgen ${ }^{20)}$ recently proposed some distinguishing features of a form of subclinical ED that she refers to as anorexia athletica. The athletes with subclinical ED show signs of disordered eating patterns but fail to meet the strict DSM- III - R criteria for ED. Moreover, individuals with subclinical ED don't exhibit severe emotional distress and specific psychopathologies that go beyond concerns about weight and the use of weight reduction methods, which are seen in individuals with true clinical ED. Bells and Menorah $^{2)}$ suggest that the survey with inventories such as EAT-26 and EDI determines the combined prevalence of clinical ED and subclinical ED. Actually, a study of Sundgot-Borgen ${ }^{20)}$ revealed that, of elite Norwegian female athletes classified as being at-risk for ED using the above inventory, $48 \%$ and $42 \%$ had clinical and subclinical ED, respectively. The study of Suematsu ${ }^{19)}$ indicated that $85 \%$ of the Japanese females who were suspected to have ED by screening with EAT-26 had clinical ED. However, it is not evident that this sensitivity for discrimination of true clinical ED in nonathletic females can be directly applied to the athletic population. Considering the findings of the Sundgot-Borgen's study ${ }^{20)}$, it is reasonable to assume that the disordered eating patterns evaluated in the present study included a subclinical as well as a true clinical ED. In order to obtain information on the prevalence of true clinical ED, further investigations using psychiatric interviews and clinical examination are needed.

The higher prevalence of disordered eating patterns in young female athletes may be primarily related to the socioculturally-imposed desire to be thin $^{22)}$. Physical attractiveness and appearance are major concerns among late female adolescents and young adults. With an increasing emphasis on thinness or leanness, females are hormonally at a distinct disadvantage. At the onset of puberty their increased estrogen levels result in an increased deposition of body fat. The adolescent females are faced with a paradox, a hormonally induced increase in body fat and a sociocultural-driven desire to be thin. In the area of athletics, the athletes are scored on the basis of how they look (aesthetic sport group), or required to maintain a low body weight for a more efficient performance (endurance sport group). This demands to be thin for optimizing performance are coupled with sociocultural factors that have an impact on the nonathletes. Consequently, the vulnerability to disordered eating patterns may be compounded in female athletes involved in sports where leanness is emphasized ${ }^{22)}$.

Factors such as lower body weight and fat ${ }^{5.11)}$ and a lower dietary intake $e^{4.12 .13 .14)}$ have been associated with athletic menstrual dysfunction. The work of Frisch and McArthur ${ }^{5)}$ suggested that a critical percent of body fat was necessary for the onset and maintenance of menstrual cycles. It has been also demonstrated that amenorrheic athletes have a lower energy intake $e^{4 \cdot 12.13 .14)}$ and a higher prevalence of disordered eating 
patterns ${ }^{3,6)}$ than their eumenorrheic counterparts. In the present study, disordered eating patterns were observed more frequently, the incidence of amenorrhea was higher, and the obesity index and BMI were lower in endurance I and aesthetic groups. In addition, further analyses using the data from all athletes indicated that amenorrheic athletes had significantly higher prevalence of disordered eating patterns and significantly lower obesity index and BMI compared to eumenorrheic or oligomenorrheic plus hypermenorrheic athletes. These findings suggest that preoccupation to be thin for improving athletic performance may lead to a dietary restriction, which causes weight losses and consequent reproductive irregularity.

In summary, this survey documented that Japanese female athletes have a strong desire for weight losses so as to improve their athletic per. formance. A higher number of athletes than nonathletes had the disordered eating patterns. Disordered eating patterns were more prevalent in the athletes involved in weight-conscious sports (endurance I and aesthetic groups), compared to nonathletes or even athletes involved in sports in which weight control is not emphasized. In the sport categories with a higher prevalence of disordered eating patterns, the incidence of amenorrhea was higher, and the obesity index and BMI were lower. This suggests a close relationship among undernutrition, a low body weight, and menstrual dysfunction.

\section{Acknowledgements}

This work was supported by the grant (No 07680152) from the Ministry of Education.

(Received, Mar. 27, 1996)

\section{References}

1) American Psychiatric Association. Diagnostic and Statistical Manual of Mental Disorders, Author, Washington, DC (1989)

2) Bells, K. A. and Menorah, M. M. The prevalence and consequences of subclinical eating disorders in female athletes. Int. J. Sport Nutr., (1994), 4, 175195.

3) Brooks-Gunn, J., Warren, M. P. and Hamilton, L. H. The relation of eating problems and amenorrhea in ballet dancers. Med. Sci. Sports Sci., (1987), 19, 4144.

4) Drinkwater, B. L., Nilson, D., Chesnut, C. H., Bremmer, A, J., Shainholtz, S. and Southworth, M. Bone mineral content of amenorrheic and eumenorrheic athletes. N. Engl. J. Med., (1984), 311, 277-281.

5) Frisch, R. E. and McArthur, J. W. Menstrual cycles : fatness as a determination of minimum weight for height necessary for their maintenance or onset. Science, (1974), 185, 949-951.

6) Gadpaille, W. J., Sanborn, C. F. and Wagner, W. W. Athletic amenorrhea, major affective disorders, and eating disorders. Am. J. Psychiatry, (1987), 144. 939-942.

7) Garner, D. M. and Garfinkel, P. E. The eating attitudes test : An index of the symptoms of anorexia nervosa. Psychol. Med., (1979), 9, 273-279.

8) Garner, D. M., Olmstead, M. P., Bohr, Y. and Garfinkel, P. E. The Eating Attitude Test: psychometric features and clinical correlates. Psychol. Med., (1982), 12, 871-878.

9) Garner, D. M., Olmstead, M. P. and Polivy, J. Development and validation of a multidimensional eating disorder inventory for anorexia nervosa and bulimia. Int. J. Eating Disorders, (1983), 2, 15-34.

10) Loucks, A. B. and Horvath, S. M. Exercise-induced stress responses of amenorrheic and eumenorrheic runners. J. Clin. Endocrinol. Metab., (1984), 59, $1109-1120$.

11) Loucks, A. B. and Horvath, S. M. Athletic amenorrhea: a review. Med. Sci. Sports Exerc., (1985), 17. 56-72.

12) Marcus, R., Cann, C., Madvig. P., Minkoff, J., Coddard, M., Bayer, M., Martin, M., Gaudini, L., Haskell. W. and Genant, H. Menstrual function and bone mass in elite women distance runners. Ann. Intern. Med., (1985), 102, 158-163.

13) Myerson, M., Gutin, B., Warren, M. P., May, M. T., Contento, I., Lee,M., Pi-Sunyer, F. X., Bierson, R. N. and Brooks-Gunn, J. Resting metabolic rate and energy balance in amenorrheic and eumenorrheic runners. Med. Sci. Sports Exerc., (1991), 23, 15-22.

14) Nelson, M. E., Fisher, E. C., Catosos, P. D.. Meredith, C. N., Turksoy, R. N. and Evance, W. J. Diet and bone status in amenorrheic runners. Am. J. Clin. Nutr., (1986), 43, 910-916.

15) Nomura, S. Eating disorder as a psychosomatic disease. J. Clin. Sports Med., (1994), 11, 397-400 (in Japanese)

16) Okano, G., Taguchi, M., Mu, Z., Sato, Y., Kaji, M. and Sugiura, K. A survey comparing nutritional 
status and exercise training programs between adolescent Japanese and Chinese athletes. Jpn. J. Phys. Fitness Sports Med., (1993), 42, 446-454.

17) Sanborn, C. F., Albrecht, B. H. and Wagner, Jr, W. W. Athletic amenorrhea : a lack of association with body fat. Med. Sci. Sports Exerc., (1987), 19, 207212.

18) Seiki, K. On nutritional survey of the Japanese candidates for Olympic Games. J. Health Phys. Educ. Rec., (1992), 42, 612-618(in Japanese).

19) Suematsu, H., Takano, A., Kuboki, T., Fukino, O., Kitagawa, T. and Fujita, T. Validation of a short version of Eating Attitude Test (EAT), In., Tutui, S, Annual report in 1985 by the Research Group of Anorexia Nervosa in the Ministry of Health and Walfare, the Ministry of Health and Walfare,
Tokyo, (1986), 30-38(in Japanese).

20) Sundgot-Borgen, J. Prevalence of eating disorders in elite female athletes. Int. J. Sport Nutr., (1993), 3, 29-40.

21) Warren, M. P. Effects of undernutrition on reproductive function in the human. Endocr. Rev., (1983), 4, 363-377.

22) Willmore, J. H. Eating and weight disorders in the female athlete. Int. J. Sport Nutr., (1991), 1, 104117.

23) Yamanaka, R., Katayose, M., Yukawa, K., Tahara, Y., Tsunawake, N. and Mori, S. Dietary conditions on elite athletes in Nagasaki prefecture. Jpn. J. Phys. Fitness Sports Med., (1994), 43, 92-103 (in Japanese). 


\section{Appendix : Questionnaire}

\section{A. Physical characteristics and athletic level}

Age: Sex:

Height: Weight: Desired weight:

Occupation: Major sports:

Level (check one):

1) International 2) National (the Japanese Championship Meet)

3) National (the Japanese Collegiate Championship Meet)

4) National (Other National Meet) 5) Regional

B. Desire of weight loss and its reason

How do you want to change your present weight?
1) Increase
2) decrease
3) maintain

If you want to decrease your weight, please check one for your major reason.

1) Others making remarks about you being overweight

2) Feel fat

3) Slimming down certain parts of body 4) Improvement of performance

5) Model like figure 6) Others (if any)

C. Menstrual status

Do you have menstrual period now? (check one)

1) Yes, regularly every month (menstrual cyclic lengths of 25-38 days)

2) Yes, but irregularly

3) No, I have not had menstruated for three months or more (excluding pregnancy) 